\title{
Impact of COVID-19 Pandemic on Usage of Electronic Financial Products
}

\section{Bilal Ahmad Sheikh, Sabbey Sharma*, Sudhakar Dwivedi and Ashish K. Isher}

\author{
Sher-e-Kashmir University of Agricultural Sciences \& Technology of Jammu, JEK, India
}

*Corresponding author: sabbeysharma666@gmail.com

Received: $10-03-2021$

Revised: 09-05-2021

Accepted: 04-06-2021

\section{ABSTRACT}

Operating of financial products through electronic mechanism are very comfortable, time saving process and helps to maintain social distancing amid current global pandemic; since the adoption rates of electronic financial products are very low. An attempt has been made in the current study to check the variation on usage of financial products through electronic mechanism amid COVID-19 pandemic. The primary data of this Study were collected from Banking Customers and have been identified on random basis from Jammu \& Kashmir. The filled up response was collected successfully from 200 respondents, however from collected 200 responses 180 responses were valid and 20 responses were incomplete and hence eliminated from the current study. Based on the survey data generated through 180 banking customers were analyzed and the corresponding implications are discussed in the work.

Keywords: e-Banking, Electronic Financial products, and COVID-19 pandemic

For quite a long time monetary organizations have utilized amazing PC organizations to computerize a great many day by day exchanges. During the 1950s the Bank of America was one of the primary establishments to build up the possibility that electronic PCs could assume control over the financial undertakings of taking care of checks and adjusting accounts, which was, around then, very work concentrated. Different foundations steadily joined the exertion and advanced away from utilizing paper checks and toward all-electronic banking. Information preparing machines, automated archive arranging, and the innovation of optical character acknowledgment (a PC application that interprets transcribed or typewritten words into text that can be machine-altered) were a couple of the advancements which permitted this development. The main electronic financial machines had the option to track stores and withdrawals from every customer, make account balance data accessible promptly, screen overdrafts, stop installments, and hold reserves. The machines answerable for this work today are as careful and solid as the financial business expects them to be. Electronic banking laid the foundation for speed and comfort in individual and (business) banking. The spread of PC use has added another layer of accommodation and speed to the cycle. Electronic banking permits clients of most banks to do their banking at any hour of the day, paying little mind to the bank's working hours. On the off chance that clients decide to do such things as move assets or cover tabs, they can typically do as such from anyplace Internet access is accessible. Web based banking normally offers bank articulations, electronic bill installment, reserves moves between

How to cite this article: Sheikh, B.A., Sharma, S., Dwivedi, S. and Isher, A.K. (2021). Impact of COVID-19 Pandemic on Usage of Electronic Financial Products. Agro Economist - An International Journal, 08(01) 23-28.

Source of Support: None; Conflict of Interest: None 
a client's checking and investment accounts (or to another client's record), advance applications and exchanges, and buying or deals of speculations, all of which permit clients to keep up their records without making an excursion to the bank itself. At the point when assets are moved between accounts by electronic methods, it is called an electronic assets move (EFT). The Electronic Fund Transfer Act, passed by the central government in 1978, set up that an electronic assets move is any monetary exchange that begins from a phone, electronic terminal, PC, or attractive tape (stockpiling tape of the sort utilized in video or sound cassettes). A wire move is the electronic exchange of assets over an organization controlled and kept up by many banks far and wide. Normally wire moves are saved for moving enormous amounts of cash. Wire moves permit individuals in various geographic areas to move cash without any problem. The wire move installment framework called Fed wire (Federal Reserve Wire Network) interfaces the workplaces of the Federal Reserve (the national bank of the U.S. government), the U.S. Depository (the division of the government that deals with the nation's income), and other government organizations and foundations.

\section{Financial Products}

Financial Products refer to instruments that help in saving, investing, get insurance or get a mortgage. These are issued by various banks, financial institutions, and stock brokerages, insurance Providers, credit card agencies and government sponsored entities (Ajzen, 2002). Financial Products are categorized in terms of their type or underlying asset class, volatility, risk and return. Some of the important examples of Financial Products are Accounts and deposits, Loans, Cards, Insurance, Shares, Bonds, Treasury bills, Mutual funds etc.

\section{Electronic Financial Products}

All Financial Products are being supported and used through electronic means due to the development of technology (Gupta, 2008). List of important Electronic Financial Products that can be handled with e- Banking by Banking Customers are as follows:

- Electronic Fund Transfer (NEFT RTGS IMPS) through e-Banking.

Print ISSN : 2350-0786
- Using Debit Card for online Transaction through e-Banking.

- Managing Credit card through e-Banking.

- Investments on Derivatives through e-Banking.

- Paying Insurance Premium through e-Banking.

- Mutual funds Investments through e-Banking.

- Loan EMI Payments through e-Banking.

- Investments on Futures and Options through e-Banking.

- Online share trading e-Banking.

The present study attempts at studying the variations on usage levels of electronic financial products amid COVID-19 Pandemic.

\section{MATERIALS AND METHODS}

The primary data for the present study were collected from the Banking Customers and these customers were identified on random basis, the filled up response was collected successfully from 200 respondents, however from collected 200 responses 180 responses were valid and 20 responses were incomplete and hence eliminated from the current study. Hence the sample size for the present work is treated as 180 comprising the Banking customers. The research was conducted in Srinagar city, which is the summer capital city of Union Territory of Jammu and Kashmir. The sample size selected for the present study was 200 using stratified random sampling method. However, out of the collected 200 responses 180 responses were valid and 20 responses were incomplete and hence eliminated. The primary data for the present study is collected during the period July 2020 to September 2020. The data collected were coded and transferred in to Statistical package for Social Science (SPSS) for the purpose of analysis.

\section{Hypothesis}

$\mathbf{H}_{1}$ : There are no variations between usage levels of electronic financial products amid COVID-19 Pandemic.

\section{RESULTS AND DISCUSSION}

Variations on usage levels of Online Trading of Derivatives amid COVID-19 pandemic

The variations between usage levels of Online

Online ISSN : 2394-8159 
Trading of Derivatives amid COVID-19 pandemic are defined in Hypothesis-1 taken up and its results are shown in Table 1 as an outcome of one way ANOVA model conceptualized usage levels of online Trading of Derivatives amid COVID-19 pandemic was categorized into three groups such as Not used, Low intensity usage and high intensity usage for identifying variations. From the results of this one way ANOVA model as shown in table 1, it can be inferred that the $\mathrm{F}$ value of 3.848 corresponding to Online Trading of Derivatives amid COVID-19 pandemic are found to be significant at 5 percent level. Hence, hypothesis- 1 is rejected at 5 percent level of significance. This result clearly shows that there exist significant variations between usage levels of Online Trading of Derivatives amid COVID-19 pandemic In order to identify the exact variations among different levels of Online Trading of Derivatives amid COVID-19 pandemic, multiple comparisons were made with LSD method.

Based on the value of mean differences, it can be inferred that the highest usage levels of Online Trading of Derivatives amid COVID-19 pandemic is identified with not used of Online Trading of Derivatives, the next higher usage levels of Online Trading of Derivatives amid COVID-19 pandemic is identified with Low intensity usage of Online Trading of Derivatives and the low usage levels of Online Trading of Derivatives amid COVID-19 pandemic is identified with High intensity usage of Online
Trading of Derivatives (Table 1). The variations in usage levels of Online Trading of Derivatives amid COVID-19 pandemic between Not used and Low Intensity usage of Online Trading of Derivatives are found to be significant at 5 percent level, Similarly variations in the usage levels of Online Trading of Derivatives amid COVID-19 pandemic between Low Intensity usage and High Intensity usage of Online Trading of Derivatives are found to be significant at 5 percent level. However the variations in usage levels of Online Trading of Derivatives amid COVID-19 pandemic between 'Not used' and 'High intensity usage of Online Trading of Derivatives' are not found to be significant at 5 percent level.

\section{Variations on usage levels of Online Payment of Insurance Premium amid COVID-19 pandemic}

The variations in the usage levels of Online Payment of Insurance Premium amid COVID-19 pandemic are defined in hypothesis- 1 taken up and its results are shown in table 2 as an outcome of one way ANOVA model conceptualized. Usage levels of Online Payment of Insurance Premium were categorized into three groups such as Not used, Low intensity usage and high intensity usage for identifying variations. From the results of this one way ANOVA model as shown in table 2, it can be inferred that the $\mathrm{F}$ value of 3.709 corresponding to usage levels of Online Payment of Insurance Premium amid COVID-19 pandemic are found to be significant at

Table 1: Variations on usage levels of Online Trading of Derivatives

\begin{tabular}{llllll}
\hline Dependent Variable & & Sum of Squares & Df & Mean Square & F \\
\hline COVID-19 & Between Groups & 203.441 & 2 & 101.720 & $3.848^{*}$ \\
& Within Groups & 31642.796 & 1197 & 26.435 & \\
& Total & 31846.237 & 1199 & & \\
\hline
\end{tabular}

Multiple Comparisons

LSD

\begin{tabular}{llllll}
\hline Dependent Variable & $\begin{array}{l}\text { Online Trading of } \\
\text { Derivatives }\end{array}$ & $\begin{array}{l}\text { Online Trading of } \\
\text { Derivatives }\end{array}$ & Mean Difference & Std. Error & \multirow{2}{*}{ Sig. } \\
\hline COVID-19 & Not used & Low intensity usage & $1.45387^{*}$ & .64228 & 0.024 \\
& High intensity usage & -1.77554 & 1.15997 & 0.126 \\
& \multirow{2}{*}{ Low intensity usage } & Not used & $-1.45387^{*}$ & 0.64228 & 0.024 \\
& High intensity usage & Not intensity usage & $-3.22941^{*}$ & 1.30786 & 0.014 \\
& & Low intensity usage & $3.22941^{*}$ & 1.15997 & 0.126 \\
& & & & 1.30786 & 0.014 \\
\hline
\end{tabular}

* Significant at 5 percent level; Source: Computed from primary data. 
Table 2: Variations on usage levels of Online Payment of Insurance Premium

\begin{tabular}{llllll}
\hline Dependent Variable & & Sum of Squares & Df & Mean Square & F \\
\hline COVID-19 & Between Groups & 196.125 & 2 & 98.062 & $3.709^{*}$ \\
& Within Groups & 31650.112 & 1197 & 26.441 & \\
& Total & 31846.237 & 1199 & & \\
\hline Multiple Comparisons & & & & \multirow{2}{*}{ Sig. } \\
\hline LSD & & & & 0.114 \\
Dependent Variable & Online Trading of & Online Trading of & Mean Difference & Std. Error & 0.033 \\
COVID-19 & Derivatives & Derivatives & & 0.50888 & 0.114 \\
& Not used & Low intensity usage & 0.80557 & 0.98453 & 0.008 \\
& & High intensity usage & $-2.10151^{*}$ & 0.50888 & 0.033 \\
& Low intensity usage & Not used & -0.80557 & 1.08551 & 0.98453 \\
\hline
\end{tabular}

* Significant at 5 percent level; Source: Computed from primary data.

5 percent level. Hence hypothesis- 1 is rejected at 5 percent level of significance. This result clearly shows that there exist significant variations in the usage levels of Online Payment of Insurance Premium amid COVID-19 pandemic. In order to identify the exact variations between usage levels of Online Payment of Insurance Premium, multiple comparisons were made with LSD method (Table 2).

The highest usage levels of Online Payment of Insurance Premium amid COVID-19 pandemic are identified with Not used, the next higher value is identified with Low intensity usage of Online Payment of Insurance Premium and the low intensity usage is identified with High intensity usage of Online Payment of Insurance Premium amid COVID-19 (Table 2). From the details provided in the table 2, it can be noted that, the variations between Not used and High Intensity usage of Online Payment of Insurance Premium are found to be significant at 5 percent level, Similarly variations between Low Intensity usage and High Intensity usage of Online Payment of Insurance Premium are found to be significant at 5 percent level. However the variations between Not used and High Intensity usage of Online Payment of Insurance Premium are not found to be significant at 5 percent level.

\section{Insignificant variations in Behavioral Intention}

The variations between the usage levels of Online Financial Products such as Usage of Credit Card through e-Banking, Usage of Debit card Through e-Banking, Usage Intensity of e-Banking for Mutual funds, Usage Intensity of Futures and Options Through e-Banking, Usage Intensity of Online Share Trading, Usage Intensity of Electronic Fund Transfer through e-Banking, Paying of Loan payments through e-Banking (Table 3), as an outcome of one way ANOVA model conceptualized. From the results of one way ANOVA, it can be inferred that the $\mathrm{F}$ values of $0.060,2.252,0.182,2.744,1.074$, 0.220 and 1.574. Corresponding to the factors such as usage of Credit Card through e-Banking, usage of Debit card through e-Banking, usage intensity of e-Banking for Mutual funds, usage intensity of Futures and Options Through e-Banking, Usage Intensity of Online Share Trading, usage intensity of Electronic Fund Transfer through e-Banking, Paying of Loan payments through e-Banking, considered as a grouping variables are Not found to be significant at 5 percent level amid COVID-19 Pandemic.

The factors such as usage of Credit Card through e-Banking, usage of Debit card through e-Banking, usage intensity of e-Banking for Mutual funds, usage intensity of Futures and Options Through e-Banking, Usage Intensity of Online Share Trading, usage intensity of Electronic Fund Transfer through e-Banking, Paying of Loan payments through e-Banking are not found to be varying significantly with COVID-19 Pandemic, hence hypothesis-H1 is accepted. 
Table 3: Behavioral Intentions

\begin{tabular}{|c|c|c|c|c|c|c|c|}
\hline $\begin{array}{l}\text { Dependent } \\
\text { Variable }\end{array}$ & Independent Variable & & Sum of Squares & df & $\begin{array}{l}\text { Mean } \\
\text { Square }\end{array}$ & F & Sig. \\
\hline \multirow[t]{23}{*}{ COVID-19 } & \multirow{3}{*}{$\begin{array}{l}\text { Usage of Credit Card } \\
\text { through Internet Banking }\end{array}$} & Between Groups & 3.177 & 2 & 1.588 & \multirow[t]{3}{*}{0.060} & \multirow[t]{3}{*}{0.942} \\
\hline & & Within Groups & 31843.060 & 1197 & 26.602 & & \\
\hline & & Total & 31846.237 & 1199 & & & \\
\hline & \multirow{3}{*}{$\begin{array}{l}\text { Usage of Debit card Through } \\
\text { Internet }\end{array}$} & Between Groups & 119.388 & 2 & 59.694 & \multirow[t]{3}{*}{2.252} & \multirow[t]{3}{*}{0.106} \\
\hline & & Within Groups & 31726.849 & 1197 & 26.505 & & \\
\hline & & Total & 31846.237 & 1199 & & & \\
\hline & \multirow{3}{*}{$\begin{array}{l}\text { Usage Intensity of Internet } \\
\text { Banking for Mutual funds }\end{array}$} & Between Groups & 9.682 & 2 & 4.841 & \multirow[t]{3}{*}{0.182} & \multirow[t]{3}{*}{0.834} \\
\hline & & Within Groups & 31836.554 & 1197 & 26.597 & & \\
\hline & & Total & 31846.237 & 1199 & & & \\
\hline & \multirow{3}{*}{$\begin{array}{l}\text { Usage Intensity of Futures } \\
\text { and Options Through } \\
\text { Internet Banking }\end{array}$} & Between Groups & 145.353 & 2 & 72.677 & \multirow[t]{3}{*}{2.744} & \multirow[t]{3}{*}{0.065} \\
\hline & & Within Groups & 31700.883 & 1197 & 26.484 & & \\
\hline & & Total & 31846.237 & 1199 & & & \\
\hline & \multirow{3}{*}{$\begin{array}{l}\text { Usage Intensity of Online } \\
\text { Share Trading }\end{array}$} & Between Groups & 57.061 & 2 & 28.531 & \multirow[t]{3}{*}{1.074} & \multirow[t]{3}{*}{0.342} \\
\hline & & Within Groups & 31789.176 & 1197 & 26.557 & & \\
\hline & & Total & 31846.237 & 1199 & & & \\
\hline & \multirow{3}{*}{$\begin{array}{l}\text { Usage Intensity of Electronic } \\
\text { Fund Transfer through } \\
\text { Internet Banking }\end{array}$} & Between Groups & 11.708 & 2 & 5.854 & \multirow[t]{3}{*}{0.220} & \multirow[t]{3}{*}{0.802} \\
\hline & & Within Groups & 31834.529 & 1197 & 26.595 & & \\
\hline & & Total & 31846.237 & 1199 & & & \\
\hline & \multirow{5}{*}{$\begin{array}{l}\text { Paying of Loan payments } \\
\text { through Internet Banking }\end{array}$} & Between Groups & 83.528 & 2 & 41.764 & \multirow[t]{5}{*}{1.574} & \multirow[t]{5}{*}{0.208} \\
\hline & & Within Groups & 31762.709 & 1197 & 26.535 & & \\
\hline & & Total & 31846.237 & 1199 & & & \\
\hline & & Within Groups & 31844.143 & 1197 & 26.603 & & \\
\hline & & Total & 31846.237 & 1199 & & & \\
\hline
\end{tabular}

*Significant at 5 percent level; Computed from primary data.

There are significant variations exist between usage levels of Online Trading of Derivatives. The highest variation is identified with not used of Online Trading of Derivatives, the next higher variation is identified with Low intensity usage of Online Trading of Derivatives and the low variation is identified with High intensity usage of Online Trading of Derivatives. There are also significant variations exist between usage levels of Online Payment of Insurance Premium. The highest variation is identified with not used of Online Payment of Insurance Premium, the next higher variation is identified with Low intensity usage of Online Payment of Insurance Premium and the low variation is identified with High intensity usage of Online Payment of Insurance Premium. It is explored that usage of Credit Card through e-Banking, usage of Debit card Through e-Banking, usage intensity of e-Banking for Mutual funds, usage intensity of Futures and Options through
e-Banking, usage intensity of Online Share Trading, usage intensity of Electronic Fund Transfer through e-Banking, Paying of Loan payments through e-Banking were not found to be varying significantly amid COVID-19 pandemic.

\section{CONCLUSION}

It is concluded that Electronic Financial Products are changing physical usage of financial Products worldwide. Today, the click of the mouse and mobile with internet connection offers lot of transactions regarding electronic Financial Products. Still the adoption rates of electronic Financial Products are very low. Hence, banking Industry should motivate their customers to adopt Electronic Financial Products as maximum banking customers are non-users of Electronic Financial Products and hence during COVID-19 pandemic, to follow social 
distancing and break the spread chain of corona virus it is important for banking customers to make usage of different platforms to use electronic mechanisms to do baking from comfort of home or offices.

\section{REFERENCES}

Ajzen, I. 2002. Perceived behavioral control, self-efficacy, locus of control, and the theory of planned behavior. Journal of Applied Social Psychology, 3(2): 665-683.

Gupta, P.K. 2008. Internet banking in India: consumer concerns and bank strategies. Global Journal of Business Research, 2(1): 43-51.

Hofstede, G. 2007. A European in Asia. Asian Journal of Social Psychology, 10(3): 16-25.

Jayshree, C. 2013. Internet banking-benefits and challenges in an emerging economy. International Journal of Research in Business Management, 1(1): 19-26.
Lichtenstein, S. and Williamson. 2006. Understanding consumer adoption of internet banking: an interpretive study in the Australian banking context. Journal of Electronic Commerce Research, 7(2): 50-66.

Margaret and Thompson. 2000. Factors influencing the adoption of internet banking. Journal of the Association for Information Systems, 1(1): 115-129.

Mohamed, I. 2012. Factors influencing the adoption of e-banking in Sudan: Perceptions of Retail Banking Clients. Journal of Internet Banking and Commerce, 17(3): 01-17.

Baten, M.A. 2010. E-Banking of economical prospects in Bangladesh. Journal of Internet Banking and Commerce, 15(2): 01-10.

Sheikh, B.A. and Rajmohan, P. 2017. Electronic non financial products. EPRA International Journal of Research and Development, 2(8): 07-14. 